\title{
PLANT COMMUNITY COMPOSITION ALTERED BY LONG- TERM NITROGEN ADDITION HAS MINOR CONTRIBUTION TO PLANT NUTRIENT STATUS AT THE COMMUNITY LEVEL
}

\author{
SU, Y. $.^{1,2,3}-$ LE, J. J. ${ }^{1,2,3}-$ MA, X. F. ${ }^{1,3}-$ LI, K. H. ${ }^{1,2,4^{*}}-$ GONG, Y. M. ${ }^{1,2}-$ AHMED, Z. ${ }^{5}-$ \\ HAN, W. X. ${ }^{1,6}-$ LIU, X. J. ${ }^{1,6^{*}}$
}

${ }^{1}$ State Key Laboratory of Desert and Oasis Ecology, Xinjiang Institute of Ecology and Geography, Chinese Academy of Sciences, Urumqi 830011, China

${ }^{2}$ Bayinbuluk Grassland Ecosystem Research Station, Xinjiang Institute of Ecology and Geography, Chinese Academy of Sciences, Bayinbuluk 841314, China

${ }^{3}$ University of Chinese Academy of Sciences, Beijing 100049, China

${ }^{4}$ CAS Research Center for Ecology and Environment of Central Asia, Urumqi 830011, China

${ }^{5}$ Cele National Station of Observation and Research for Desert-Grassland Ecosystem, Xinjiang Institute of Ecology and Geography, Chinese Academy of Sciences, Xinjiang 848300, China

${ }^{6}$ Beijing Key Laboratory of Farmland Soil Pollution Prevention and Remediation, College of Resources and Environmental Sciences, China Agricultural University, Beijing 100193, China

${ }^{*}$ Corresponding authors

e-mail:liu310@cau.edu.cn; College of Resources and Environmental Sciences, China Agricultural University, Yuanmingyuan West Road 2\#, Haidian District, Beijing 100193, China (Liu, X. J.)

e-mail: grassland1998@126.com; CAS Key Laboratory of Biogeography and Bioresource in Arid Land, Xinjiang Institute of Ecology and Geography, Chinese Academy of Sciences, Urumqi 830011, China (Li, K. H.)

(Received $15^{\text {th }}$ Apr 2020; accepted 29 $9^{\text {th }}$ Jul 2020)

\begin{abstract}
Short-term nitrogen (N) deposition has exhibited great impacts on plant internal nutrient cycling in forest, grassland and desert ecosystems. However, the responses of plant nutrient status to chronic $\mathrm{N}$ deposition are not well understood, especially in alpine grasslands limited by soil $\mathrm{N}$ availability. This study used an $\mathrm{N}$ addition experiment that had been implemented since 2009 in the Tianshan mountains, northwest China, to investigate the effects of $\mathrm{N}$ addition at five levels $\left(0,1,3,9\right.$ and $15 \mathrm{~g} \mathrm{~N} \mathrm{~m}^{-2}$ year $\left.{ }^{-1}\right)$ on the leaf nutrient concentrations and stoichiometric ratios of dominant perennial grasses (Leymus tianschanicus, Festuca ovina, Agropyron cristatum and Koeleria cristata) and forbs (Potentilla anserina and Potentilla bifurca) at the species, functional group and community levels. The results showed that increasing $\mathrm{N}$ addition significantly enhanced soil available $\mathrm{N}$ concentrations and soil available $\mathrm{N}: \mathrm{P}$ ratios but had no detectable impacts on soil available phosphorus $(\mathrm{P})$ concentrations. Nitrogen addition significantly reduced forb relative biomass, ranging from $13 \%$ in control plots versus $2 \%$ in the highest $\mathrm{N}$ addition plots. Furthermore, $\mathrm{N}$ addition increased the foliar $\mathrm{N}$ concentrations and $\mathrm{N}: \mathrm{P}$ ratios for all the species, decreased foliar P concentrations for grasses, and had no significant effects on P concentrations in forbs. Plant carbon (C) concentrations remained relatively stable, resulting in reduced $\mathrm{C}: \mathrm{N}$ as $\mathrm{N}$ addition increased. In contrast, $\mathrm{N}$ addition consistently increased leaf $\mathrm{N}$ concentrations, $\mathrm{C}: \mathrm{P}$ and $\mathrm{N}: \mathrm{P}$ and decreased leaf $\mathrm{P}$ concentrations and $\mathrm{C}: \mathrm{N}$ at the community level. Regression analysis showed that soil available $\mathrm{N}$ and $\mathrm{N}: \mathrm{P}$ ratios, rather than soil available $\mathrm{P}$, were key parameters controlling plant $\mathrm{N}$ and $\mathrm{P}$ concentrations and stoichiometric ratios. Foliar $\mathrm{N}$ and $\mathrm{P}$ concentrations showed divergent responses to long-term $\mathrm{N}$ addition at the species and community levels, which implied that plant $\mathrm{N}$ and $\mathrm{P}$ cycling decoupled under $\mathrm{N}$ deposition. Grasses were more sensitive to $\mathrm{N}$ addition than forbs, resulting in significantly altered plant community composition.
\end{abstract}


These findings are important for understanding plant nutrient allocation strategies and how plants adapt to environmental changes, such as $\mathrm{N}$ deposition in alpine ecosystems.

Keywords: aboveground biomass, alpine grassland, community composition, ecological stoichiometry, nutrient cycling, nitrogen addition

\section{Introduction}

Ecological stoichiometry has been used to study the balance of multiple elements in many ecological processes (Elser et al., 2007). Plant carbon (C): nitrogen (N): phosphorus (P) stoichiometric ratios are closely related to ecosystem processes, such as nutrient cycling (Sterner et al., 2002; Lü et al., 2013; Li et al., 2016), litter decay (Manzonl et al., 2010), plant community structure and stability (Yu et al., 2010), and microbial composition (Güsewell et al., 2009). Previous studies have reported that plants tend to show stoichiometric variability in response to environmental disturbance, for instance, $\mathrm{N}$ deposition and $\mathrm{P}$ deposition (Sistla et al., 2015), but this flexibility varies across different species (Sardans et al., 2015). Therefore, determining the sensitivity of plant ecological stoichiometry is critical to clarify ecosystem patterns, processes and functions to $\mathrm{N}$ deposition.

Unprecedented increases in atmospheric nitrogen $(\mathrm{N})$ deposition have occurred in drylands of China from 1980 to 2010 and are predicted to double by 2050 (Gu et al., 2015). Nitrogen is one of the primary limiting nutrients in grasslands; $\mathrm{N}$ addition not only facilitates plant growth but also enhances primary productivity (Bai et al., 2010). Moreover, increasing $\mathrm{N}$ availability has significant effects on plant internal nutrient cycling (Burton et al., 2012). The increase in leaf $\mathrm{N}$ concentration due to $\mathrm{N}$ addition has been extensively examined in grasslands (Lü et al., 2013; Li et al., 2016), wetlands (Mao et al., 2012), deserts (Zheng et al., 2018; Li et al., 2019) and forest ecosystems (Huang et al., 2019). However, large uncertainties exist regarding the impacts of $\mathrm{N}$ addition on leaf $\mathrm{P}$ concentrations. The effects of $\mathrm{N}$ addition on leaf $\mathrm{P}$ concentrations have been shown to be positive (Menge and Field, 2007), neutral (Kozovits et al., 2007; Lü et al., 2012), or negative ( $\mathrm{Li}$ et al., 2016). Furthermore, nutrient traits in plants and their response to nutrient addition vary greatly among different species (Han et al., 2014; Hou et al., 2017; Wang et al., 2018; Lü et al., 2018). Studies in alpine grassland ecosystems are relatively scarce, and limited data are available regarding how enhanced $\mathrm{N}$ inputs affect leaf nutrient status. For example, $\mathrm{N}$ deposition enhanced the leaf $\mathrm{P}$ concentrations of Seriphidium rhodanthum but did not have a significant effect on that of Stipa capillata in alpine grasslands (Li et al., 2016). In contrast, Peng et al. (2017) found that $\mathrm{N}$ addition consistently decreased leaf $\mathrm{P}$ concentrations in alpine grasslands across a two-year period. Therefore, the existence of the potential divergent responses of plant nutrient status at the species level to $\mathrm{N}$ addition can constrain our understanding regarding the effects of $\mathrm{N}$ addition on plant internal nutrient cycling. More empirical evidence is needed to determine the effects of chronic $\mathrm{N}$ deposition on the nutrient status of plants in alpine grasslands.

To date, $\mathrm{N}$ addition affecting the plant nutrient status at the species level has been extensively investigated ( $\mathrm{Li}$ et al., 2016, 2020; Hou et al., 2017), but the responses at the functional group and community levels remain limited. It is well documented that $\mathrm{N}$ deposition has significant effects on plant community composition and that plant nutrient status at the species level does not accurately represent the community level nutrient status (Han et al., 2014; Wang et al., 2018). $\mathrm{N}$ addition has significantly increased $\mathrm{N}$ concentrations and the N:P ratio at the community level (Hou et al., 2017; Wang et al., 2018), yet Lü et al. (2018) reported that $\mathrm{N}$ addition had no impact on the leaf N:P ratio at 
the community level. Moreover, positive, negative and neutral responses of $\mathrm{P}$ concentrations to $\mathrm{N}$ addition have been shown (Hou et al., 2017; Wang et al., 2018). Considering these inconsistent results, more experimental evidence is needed to obtain a general conclusion of plant ecological stoichiometry at the community level in response to enhanced $\mathrm{N}$ deposition. Furthermore, the duration of $\mathrm{N}$ addition is relatively short, and plant ecological stoichiometry to long-term $\mathrm{N}$ addition is still unknown in alpine grassland ecosystems.

Plant N and P statuses are tightly coupled with soil nutrient availability (Ågren et al., 2012). A recent study reported that $\mathrm{N}$ addition led to the decoupling of plant internal $\mathrm{N}$ and $\mathrm{P}$ cycling in a meadow steppe (Feng et al., 2019). This occurred because $\mathrm{N}$ addition significantly enhanced soil $\mathrm{N}$ availability and then led to soil acidification affecting plantsoil stoichiometry. Previous studies showed that $\mathrm{N}$ addition consistently enhanced leaf $\mathrm{N}$ concentrations and decreased the C:N ratio, thus influencing litter decay (Manzonl et al., 2010). Leaf N:P ratios have been used to determine plant nutrient limitation (Güsewell et al., 2004; Zhan et al., 2017). Nitrogen addition significantly increased leaf N:P ratios and finally resulted in plant growth limited by soil P availability (Zheng et al., 2018; Huang et al., 2019). Compared with stoichiometric variability at the species level, that at the community level is more difficult to reach a general conclusion for the following reasons. On the one hand, the plant nutrient status response to $\mathrm{N}$ addition is greatly dependent on species identity (Lü et al., 2012). On the other hand, N addition changes plant community composition, and the relative aboveground biomass significantly impacts plant nutrient status at the community level (Wang et al., 2018). There was a new finding showing that $\mathrm{N}$ addition significantly enhanced leaf $\mathrm{N}$ concentrations for grasses and forbs at the functional group level and had non-significant effects on $\mathrm{P}$ concentrations. However, the responses of leaf $\mathrm{N}: \mathrm{P}$ ratios to $\mathrm{N}$ addition presented positive effects for grasses and neutral effects for forbs (Zhang et al., 2018). Increased $\mathrm{N}$ concentrations and negligible effects on $\mathrm{P}$ concentrations showed divergent responses of foliar $\mathrm{N}$ and $\mathrm{P}$ to $\mathrm{N}$ addition. Furthermore, studies regarding how plant nutrient status adapts to environmental disturbance are relatively limited. Simultaneously, how stoichiometric flexibility responds to $\mathrm{N}$ addition is highly variable from species to community. Therefore, more experimental evidence of plant nutrient status responses to long-term $\mathrm{N}$ addition is necessary, especially in alpine grassland ecosystems.

The Tianshan Mountains have been regarded as one of the areas critical for global biodiversity protection in temperate arid regions. The current total $\mathrm{N}$ deposition has been estimated at $8 \mathrm{~kg} \mathrm{~N} \mathrm{ha}^{-2} \mathrm{yr}^{-1}$ ( $\mathrm{Li}$ et al., 2015). Previous studies have shown that $\mathrm{N}$ addition has great consequences on plant and soil $\mathrm{C}$ and $\mathrm{N}$ cycling. For instance, $\mathrm{N}$ addition tends to increase soil $\mathrm{N}_{2} \mathrm{O}$ emissions and decrease methane uptake (Li et al., 2012; Yue et al., 2016); such results have mainly emerged from enhanced soil $\mathrm{N}$ availability by $\mathrm{N}$ addition. In addition, $\mathrm{N}$ addition generally enhanced plant growth and significantly increased plant $\mathrm{N}$ uptake (Li et al., 2015) because plant growth could be limited by soil available N. Studies regarding the effect of altered plant community composition and increased aboveground biomass due to $\mathrm{N}$ addition on plant ecological stoichiometry at the functional group and community levels in alpine grassland ecosystems are limited.

Therefore, a field experiment was designed to examine the effect of various $\mathrm{N}$ addition levels on leaf $\mathrm{C}, \mathrm{N}$ and $\mathrm{P}$ concentrations and their stoichiometric ratios at the species, functional group, and community levels by taking advantage of an 11-year experiment with various $\mathrm{N}$ addition levels $\left(0,1,3,9\right.$ and $15 \mathrm{~g} \mathrm{~N} \mathrm{~m}^{-2}$ year $\left.^{-1}\right)$ in an alpine grassland in northwest China. We tested the following hypotheses: (1) long-term $\mathrm{N}$ addition increased 
leaf $\mathrm{N}$ concentrations from species to community because of significantly enhancing soil $\mathrm{N}$ availability by $\mathrm{N}$ addition but (2) decreased $\mathrm{P}$ concentrations primarily because of the non-significant effects of $\mathrm{N}$ addition on soil $\mathrm{P}$ availability, and (3) $\mathrm{N}$ addition generally mitigates $\mathrm{N}$ limitation but exacerbates $\mathrm{P}$ limitation based on the enhanced leaf $\mathrm{N}: \mathrm{P}$ ratio.

\section{Materials and Methods}

\section{Study site and experimental set up}

This field experiment was conducted at the Bayinbuluk Grassland Ecosystem Research Station $\left(42^{\circ} 18^{\prime}-43^{\circ} 34^{\prime} \mathrm{N}, 82^{\circ} 27^{\prime}-86^{\circ} 17^{\prime} \mathrm{E}\right)$, located on the south slope of the middle section of Tianshan Mountain in northwestern China. The long-term average (1981-2012) is $282.3 \mathrm{~mm}$, with $60 \%$ of precipitation occurring in the growing season from May to September, and the mean annual temperature is $-4.8^{\circ} \mathrm{C}$ ( $\mathrm{Li}$ et al., 2015). Furthermore, this natural grassland has a mean altitude of 2,500 $\mathrm{m}$ and a total area of approximately $23,000 \mathrm{~km}^{2}$, belonging to the typical alpine and dry grassland. The soil is a Camisole according to the Food and Agriculture Organization soil classification system, with a high organic matter and $\mathrm{N}$ content and a low $\mathrm{P}$ content. Due to disturbance from human activities, the current atmospheric nitrogen deposition is approximately $8 \mathrm{~kg} \mathrm{~N} \mathrm{ha}^{-1} \mathrm{yr}^{-1}$. The dominant grass species in the ecosystem are Leymus tianschanicus, Festuca ovina, Agropyron cristatum and Koeleria cristata, contributing approximately $87 \%$ to the aboveground biomass (Fig. 1).

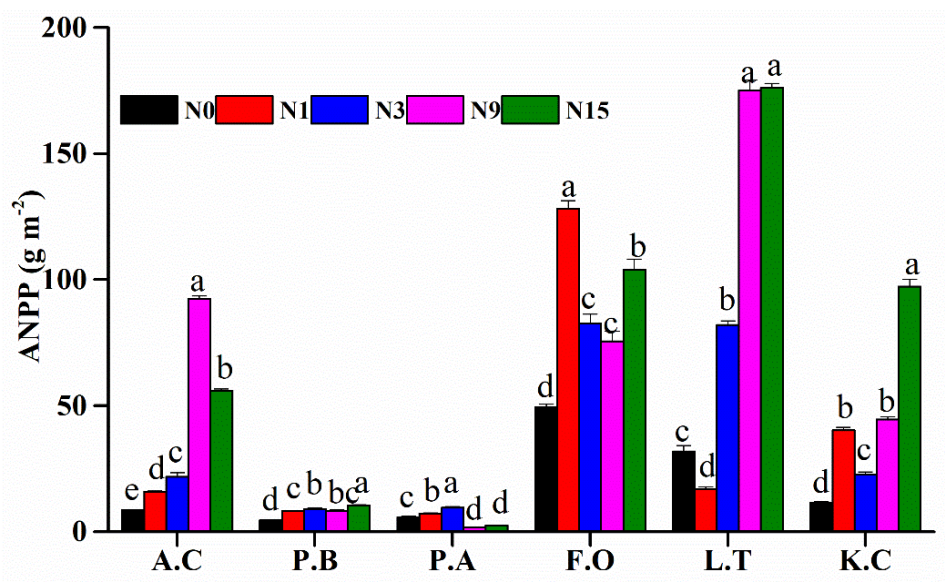

Figure 1. Responses of plant aboveground biomass to $N$ addition. Error bars $+S E$. Bars with different letters show significant differences $(P<0.05)$ between the treatments. Leymus tianschanicus (L. T), Festuca ovina (F. O), Agropyron cristatum (A. C), Koeleria cristata (K. C), Potentilla anserina (P. A), and Potentilla bifurca (P.B)

$\mathrm{N}$ addition experiments have been carried out since 2009. There were five treatments: control (N0), 10 (N1), 30 (N3), 90 (N9), and 150 (N15) $\mathrm{kg} \mathrm{N} \mathrm{ha}^{-1} \mathrm{yr}^{-1}$. Each treatment was established with four replicates, resulting in a total of 20 plots. Each $8 \times 4 \mathrm{~m}$ plot was arranged in a randomized block design, and each plot was separated by a $1 \mathrm{~m}$ buffer. Nitrogen was added to the plots as purified $\mathrm{NH}_{4} \mathrm{NO}_{3}$ in two split doses applied in early May and June each year. A weighed amount of $\mathrm{NH}_{4} \mathrm{NO}_{3}$ was dissolved in $8 \mathrm{~L}$ water and 
applied to each block using a sprayer to distribute the fertilizer evenly. The same amount of water was added to the control plots without $\mathrm{N}$ fertilizer.

\section{Plant and soil sampling and chemical measurements}

In mid-August 2019, aboveground biomass was sampled by clipping all plants in each plot using a $0.5 \times 0.5 \mathrm{~m}$ quadrat at peak biomass time. The plant samples were harvested, sorted into species and then oven-dried at $65^{\circ} \mathrm{C}$ for $48 \mathrm{~h}$. The dry mass of all living plants in each quadrat was used to estimate the aboveground species biomass based on the four replicates for each treatment. Aboveground net primary production (ANPP) was estimated as the peak aboveground biomass during the growing season (Bai et al., 2010).

Leaf samples were collected from the dominant grass species Leymus tianschanicus, Festuca ovina, Agropyron cristatum, and Koeleria cristata, and perennial forbs of Potentilla multifida and Potentilla bifurca were also collected for chemical analysis. All plant species were divided into two plant functional groups: grasses and forbs. These species represented almost $95 \%$ of the total aboveground biomass. Similar leaves were randomly selected in the subplot $(2 \mathrm{~m} \times 2 \mathrm{~m})$ from the center of each plot. The leaves were oven-dried at $65{ }^{\circ} \mathrm{C}$ to reach a constant weight, ground, and then mixed evenly for elemental analysis. Plant $\mathrm{C}$ and $\mathrm{N}$ contents were determined with an elemental analyzer (Vario micro, Hanau, Germany). The total $\mathrm{P}$ concentrations were measured by wet digestion with $\mathrm{H}_{2} \mathrm{SO}_{4}+\mathrm{HClO}_{4}$. $\mathrm{C}, \mathrm{N}$ and $\mathrm{P}$ concentrations were expressed as the nutrient content per unit mass $\left(\mathrm{mg} \mathrm{g}^{-1}\right)$.

Soil samples (0-10 cm depth) were collected from each plot in August 2019. In the center of each plot at least $2 \mathrm{~m}$ away from the edge of the plot, five soil cores were collected using a $3 \mathrm{~cm}$ diameter soil auger and were mixed into a single composite sample. All soil samples were sieved through a $2 \mathrm{~mm}$ mesh to remove roots and litter. Soil available $\mathrm{N}$ was extracted with $50 \mathrm{ml}$ of $2 \mathrm{M} \mathrm{KCl}$ solution. Then, the filtered soil extract was used to determine alkaline nitrogen concentrations with a Kjeldahl distillation system (VAP-45, Gerhaedf, German). Available soil P was measured by extracting soil with $0.5 \mathrm{M} \mathrm{NaHCO}_{3}(\mathrm{pH}=8.5)$, followed by analysis with the molybdenum blue-ascorbic acid method (Olsen et al., 1954).

\section{Calculation of data and statistical analysis}

Plant nutrient concentrations at the functional group and community levels were estimated as species relative biomass as a weighting factor, and the $\mathrm{C}, \mathrm{N}$, and $\mathrm{P}$ concentrations and nutrient stoichiometric ratio were calculated for each species in every plot (Lü et al., 2018).

All statistical analyses were performed in SPSS version 23.0 (SPSS Inc. Chicago, IL, USA). Data were tested for normality using the Kolmogorov-Smirnov test and Levene's test for equality of error variance. One-way analysis of variance (ANOVA) was applied to test whether the $\mathrm{N}$ treatment influenced the plant nutrient concentrations and stoichiometric ratios of each species, with $\mathrm{N}$ treatment as a fixed factor. Differences among treatments were analyzed by Tukey's multiple comparison post hoc test. Linear regression analyses were conducted to determine the relationships between soil available nutrient concentrations, plant nutrient concentrations and stoichiometric ratios. All figures were constructed in Origin 9.0. 


\section{Results}

\section{Responses of soil available nutrients and ANPP}

Nitrogen addition significantly enhanced the soil available $\mathrm{N}$ concentration, ranging from $189.62 \pm 10.1 \mathrm{mg} \mathrm{kg}^{-1}$ in the control plots (N0) to $267.40 \pm 4.0 \mathrm{mg} \mathrm{kg}^{-1}$ in the highest $\mathrm{N}$ addition plots (N15). However, $\mathrm{N}$ addition showed no significant effect on soil $\mathrm{P}$ availability, with a range from $7.52 \pm 0.56$ to $8.62 \pm 0.9 \mathrm{mg} \mathrm{kg}^{-1}$ (Fig. 2). The soil available $\mathrm{N}: \mathrm{P}$ ratio significantly increased across the $\mathrm{N}$ addition gradient (Fig. 2). $\mathrm{N}$ addition significantly enhanced ANPP for grass and decreased biomass for forb species, but the response of magnitude varied highly among species (Fig. 1).
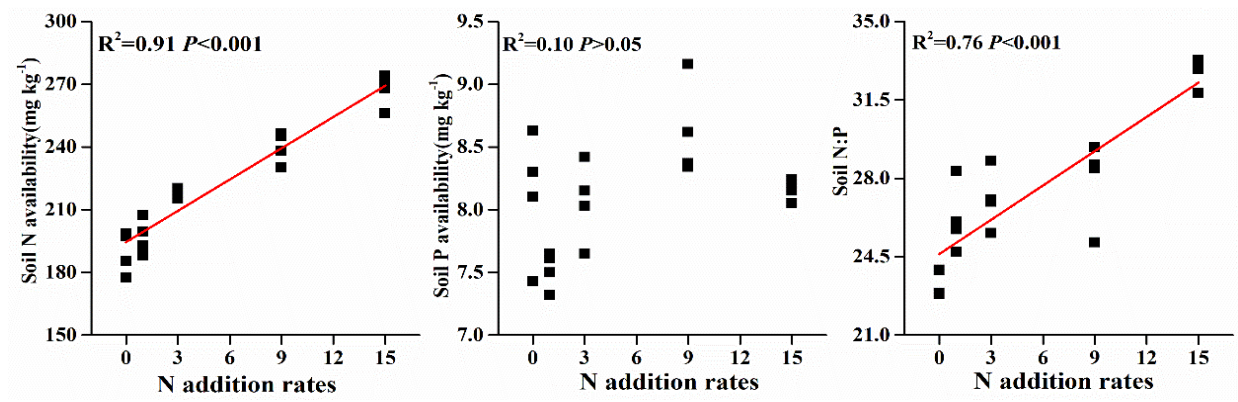

Figure 2. Relationships between nitrogen $(N)$ addition rates and soil available $N$ and phosphorus $(P)$ concentrations and available soil N:P ratios in the alpine grassland

\section{Responses of nutrient status at the species, plant functional group and community levels}

The nitrogen addition rate and species identity had significant effects on leaf $\mathrm{N}$ and $\mathrm{P}$ concentrations and the N:P ratio (Fig. 3, Table 1 ). $\mathrm{N}$ addition significantly increased the leaf $\mathrm{N}$ concentrations of the six species (Fig. 3). In contrast, the $\mathrm{P}$ concentrations in the leaves of the four plant species significantly decreased and had no effects on P.A and P.B. Plant $\mathrm{C}$ concentrations remained relatively stable across $\mathrm{N}$ addition treatments (Fig. 3, Table 1). $\mathrm{N}$ addition significantly enhanced the $\mathrm{N}: \mathrm{P}$ ratio but reduced the $\mathrm{C}: \mathrm{N}$ ratio for all grass species (Fig. 3). The ratios of $\mathrm{C}$ to $\mathrm{P}$ were insignificantly affected by P.A and P.B but significantly increased for other species (Table 1).
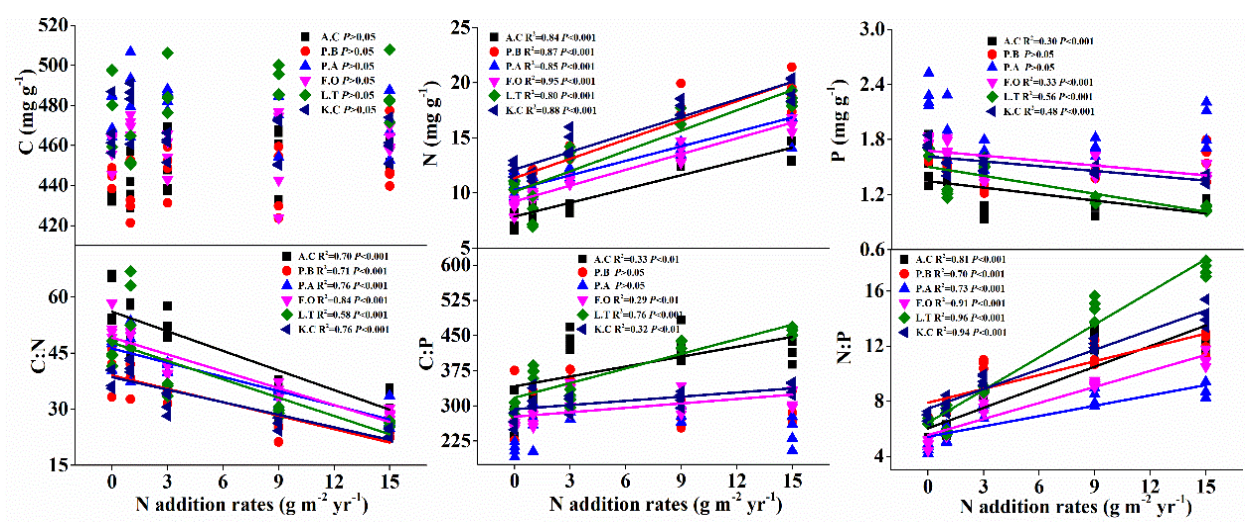

Figure 3. Relationships between plant nutrient concentrations or stoichiometric ratio and $N$ addition rates at the species level. Leymus tianschanicus (L.T), Festuca ovina (F.O), Agropyron cristatum (A.C), Koeleria cristata (K.C), Potentilla anserina (P.A), Potentilla bifurca (P.B) 
Table 1. Results of a one-way analysis of variance (ANOVA) of the dependence of leaf nutrient concentrations and stoichiometric ratios on $N$ addition. The F-ratios are presented together with their level of significance. Leaf $C, N$ and $P$ concentrations are represented. The leaf $C: N$, $C: P$ and $N: P$ ratios were also represented as mass ratios from species to community

\begin{tabular}{|c|c|c|c|c|c|c|}
\hline Plant types & $\mathbf{C}$ & $\mathbf{N}$ & $\mathbf{P}$ & $\mathrm{C}: \mathrm{N}$ & C:P & $\mathbf{N}: \mathbf{P}$ \\
\hline A.C & 0.91 & $53.53 * *$ & $13.41 * *$ & $20.32 * *$ & $19.59 * *$ & $80.52 * * *$ \\
\hline K.C & 1.00 & $42.72 * *$ & $5.85^{*}$ & $18.38 * *$ & 2.66 & $82.21 * * *$ \\
\hline P.A & 1.00 & $24.16^{* *}$ & 1.43 & $15.77 * *$ & 0.85 & $46.17 * * *$ \\
\hline P.B & 0.95 & $107.56 * * *$ & 0.57 & $48.59 * *$ & 0.31 & $172.29 * * *$ \\
\hline F.O & 1.29 & $124.96 * * *$ & $184.95 * * *$ & $31.09 * *$ & $161.9 * * *$ & $243.16^{* * *}$ \\
\hline L.T & 2.11 & $66.94 * *$ & $24.08^{* *}$ & $54.15 * *$ & $10.16^{*}$ & $128.61 * * *$ \\
\hline Forbs & 0.98 & $48.37 * *$ & 1.82 & $53.57 * *$ & 1.59 & $84.75 * * *$ \\
\hline Grasses & 1.16 & $222.65 * * *$ & $55.53 * * *$ & $65.54 * * *$ & $22.25^{*}$ & $297.88 * * *$ \\
\hline Community & 3.20 & $246.2 * * *$ & $66.4 * * *$ & $72.0 * * *$ & $26.0 * *$ & $342.9 * * *$ \\
\hline
\end{tabular}

Grasses species: Leymus tianschanicus (L.T), Festuca ovina (F.O), Agropyron cristatum (A.C) and Koeleria cristata (K.C), Forbs species: Potentilla anserina (P.A) and Potentilla bifurca (P.B), Community $=$ Grasses species + forbs species. ns indicates no significant difference. $* P<0.05$. $* * P<$ $0.01 . * * * P<0.001$

Nitrogen addition had no significant impacts on $\mathrm{C}$ concentrations and increased $\mathrm{N}$ concentrations but decreased $\mathrm{P}$ concentrations at both the plant functional group and community levels (Fig. 4, Table 1). Furthermore, $\mathrm{N}$ addition significantly enhanced the ratios of $\mathrm{C}$ to $\mathrm{P}$ and $\mathrm{N}$ to $\mathrm{P}$ but significantly reduced the ratios of $\mathrm{C}$ to $\mathrm{N}$ at the community level.

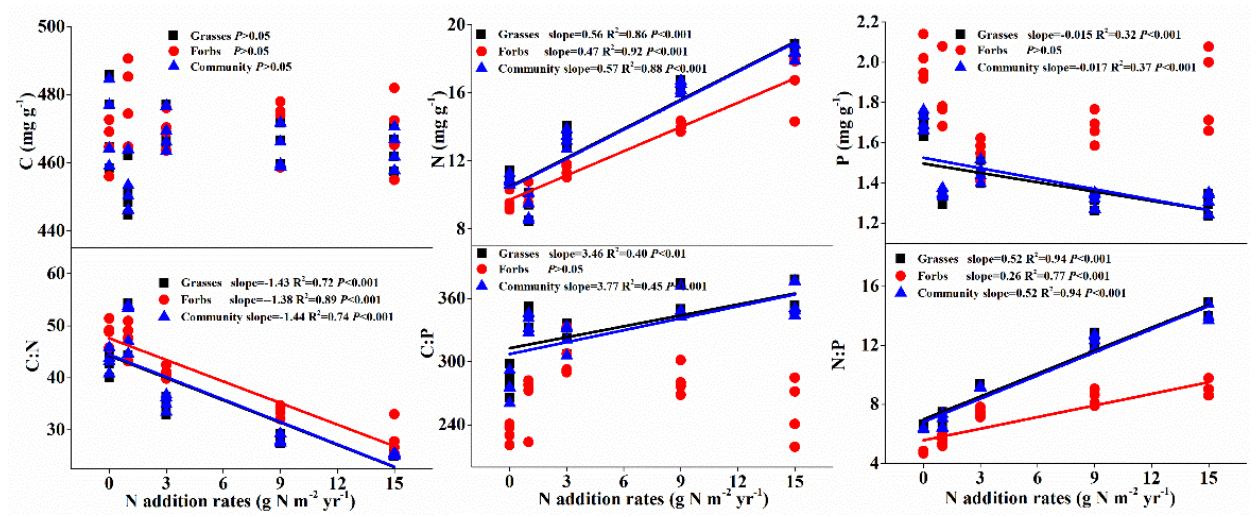

Figure 4. Relationships between plant nutrient concentrations or stoichiometric ratio and $N$ addition rates at the functional group and community levels. Leymus tianschanicus (L.T), Festuca ovina (F.O), Agropyron cristatum (A.C), Koeleria cristata (K.C), Potentilla anserina (P.A), Potentilla bifurca (P.B)

\section{Relationship between leaf nutrient status and soil available nutrients}

For all species, the results showed that altered soil nutrient availability had nonsignificant effects on $\mathrm{C}$ concentrations. Leaf $\mathrm{N}$ concentrations and ratios of $\mathrm{N}$ to $\mathrm{P}$ were positively correlated with soil available $\mathrm{N}$, while $\mathrm{P}$ concentrations and ratios of $\mathrm{C}$ to $\mathrm{N}$ were negatively correlated with soil available N concentrations (Fig. 5). Soil available $\mathrm{N}$ :P showed similar effects on leaf nutrient status with soil $\mathrm{N}$ availability. There was a 
non-significant linear relationship between $\mathrm{P}$ concentrations in leaves and soil $\mathrm{P}$ availability, but a positive relationship was observed between $\mathrm{N}$ concentrations and soil $\mathrm{P}$ availability among 4 out of 6 species. However, soil available N:P significantly affected PTP and the plant nutrient stoichiometric ratio (Fig. 5).
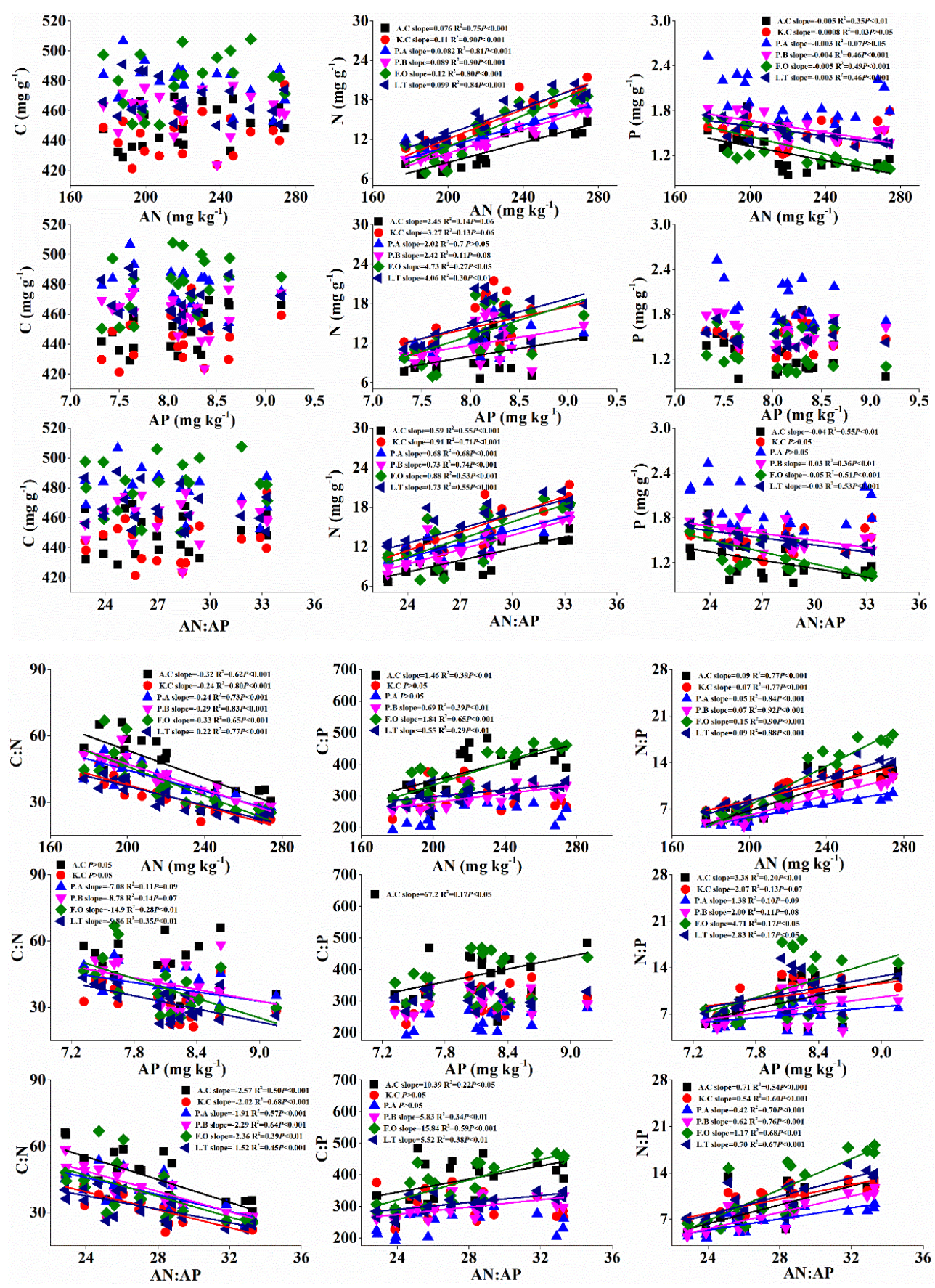

Figure 5. Relationships between plant nutrient concentrations or stoichiometric ratio and soil available nutrients (AN, AP and AN:AP) at the species level. Leymus tianschanicus (L. T),

Festuca ovina (F. O), Agropyron cristatum (A. C), Koeleria cristata (K. C), Potentilla anserina (P. A), Potentilla bifurca (P.B). Soil available nitrogen (AN), soil available phosphorus $(A P)$ and soil AN:AP ratios $(A N: A P)$ 
At the community level, soil $\mathrm{N}$ availability had no impacts on $\mathrm{C}$ concentrations but increased $\mathrm{N}$ concentrations, $\mathrm{C}: \mathrm{P}$ and $\mathrm{N}: \mathrm{P}$ ratios; at the same time, it decreased the $\mathrm{P}$ concentrations and $\mathrm{C}: \mathrm{N}$ ratio. Soil available $\mathrm{P}$ did not affect the $\mathrm{C}$ concentrations, $\mathrm{P}$ concentrations or $\mathrm{C}: \mathrm{P}$ ratio (Fig. 6). The leaf $\mathrm{N}$ concentration and $\mathrm{N}: \mathrm{P}$ ratio were positively correlated with the soil available $\mathrm{P}$, and the $\mathrm{C}: \mathrm{N}$ ratio was negatively correlated. The soil available N:P ratio revealed constant effects on the leaf nutrient status with soil $\mathrm{N}$ availability.
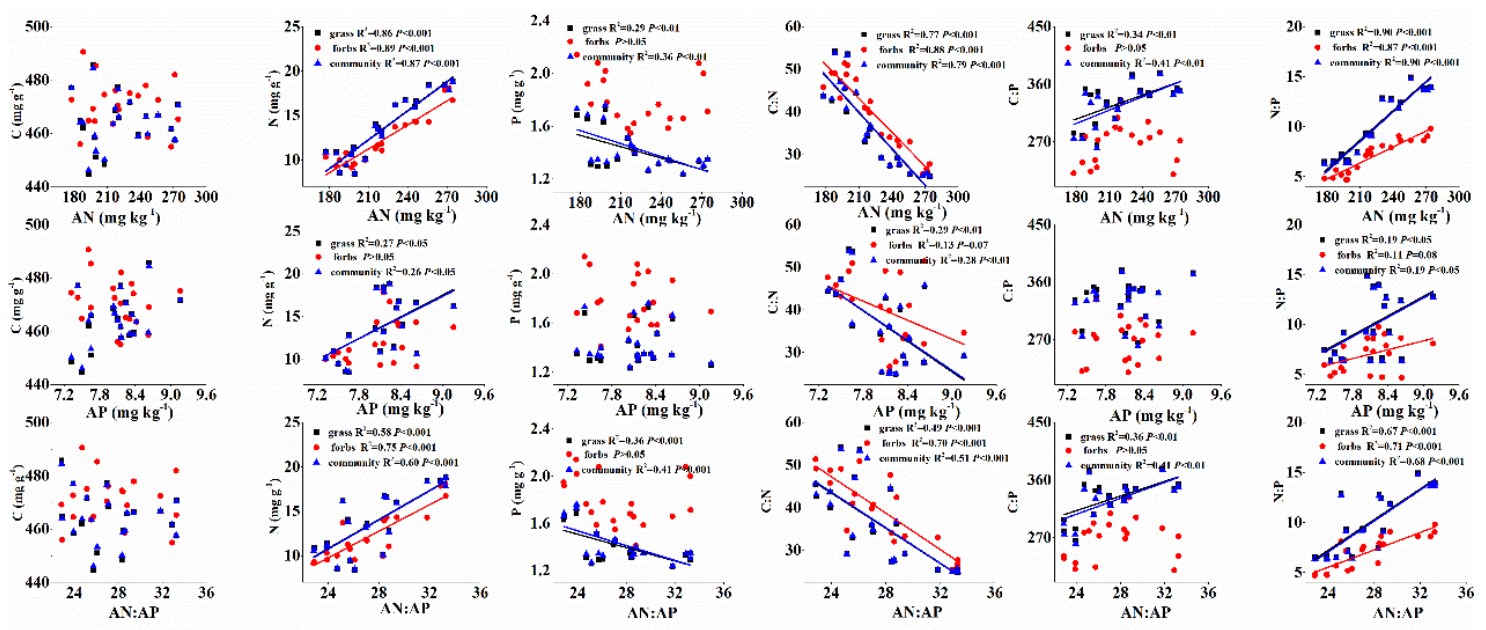

Figure 6. Relationships between plant nutrient concentrations or stoichiometric ratios and soil available nutrients (AN, AP and AN:AP) at the functional group and community levels. Grass:

Leymus tianschanicus, Festuca ovina, Agropyron cristatum and Koeleria cristata. Forbs:

Potentilla anserina and Potentilla bifurca. Community $=$ grass + forbs. Soil available nitrogen $(A N)$, soil available phosphorus $(A P)$ and soil $A N$ :AP ratios $(A N: A P)$

\section{Discussion}

\section{Responses of species biomass to $N$ addition}

Nitrogen addition significantly increased soil $\mathrm{N}$ availability and had non-significant effects on soil available $\mathrm{P}$, resulting in a higher soil AN:AP ratio. This is consistent with a study from alpine steppe (Peng et al., 2017). Altered soil available N significantly promoted grass species growth and enhanced plant biomass from $101.4 \pm 19.1 \mathrm{~g} \cdot \mathrm{m}^{-2}$ to $307.7 \pm 54.4 \mathrm{~g} \cdot \mathrm{m}^{-2}$ for the average of all $\mathrm{N}$ treatments. However, $\mathrm{N}$ addition had different effects on forb species biomass depending on species identity. Previous studies have reported that $\mathrm{N}$ addition significantly increased grass species biomass but had positive, negative and negligible impacts on forb species biomass (Han et al., 2014; Hou et al., 2017; Wang et al., 2018). These findings indicated that $\mathrm{N}$ is the limiting factor of plant growth in this grassland. The biomass responses of forb species against $\mathrm{N}$ addition indicated less sensitivity compared to grass species in our study. One possible reason could be that $\mathrm{N}$ addition might have increased the height of grass species, which would have restricted the availability of light in the lower layer of the forb species, resulting in limited plant growth (Bai et al., 2010; Zhou et al., 2018). In our study, N addition enhanced the biomass of dominant grass species and reduced the biomass of nondominant forb species, which significantly affected the plant community composition and increased the risk of loss of forb species. Nitrogen deposition showed a positive impact 
by promoting plant growth and significantly improving plant aboveground biomass for forage supply, but its negative impact appeared in the form of alteration of plant community structure that resulted in loss of biodiversity (Bai et al., 2010; Wang et al., 2018).

\section{Effects of $N$ addition on the nutrient status of leaves and stoichiometric ratios at the species level}

In the control plots, plant nutrient status revealed wide variation among species. In all species, the average concentrations of leaf $\mathrm{C}\left(463.11 \mathrm{mg} \mathrm{g}^{-1}\right), \mathrm{N}\left(10.12 \mathrm{mg} \mathrm{g}^{-1}\right)$ and $\mathrm{P}$ $\left(1.77 \mathrm{mg} \mathrm{g}^{-1}\right)$ were partly consistent with the results of previous studies on grasslands in China (He et al., 2006, 2008). In our study, plant $\mathrm{N}$ content was significantly lower compared to grassland in northern China, but our findings are supported by the results from alpine grasslands (Peng et al., 2017). Additionally, our results are also comparable with those of a previous study from alpine grasslands where multiple sites across the Tibetan Plateau have been tested (Zhou et al., 2020). It can be inferred that reduced nutrient accumulation in leaves could be the result of declined rates of plant absorption and utilization under drier and colder environments (Aerts et al., 1996). Moreover, the relatively low concentration of soil available $\mathrm{N}$ under conditions of less rainfall and low temperature would be the reason for the low plant $\mathrm{N}$ concentration in this alpine grassland (Tian et al., 2010). This can result not only from the rate of plant absorption and utilization slowing down in drier and colder environments and reducing leaf nutrient accumulation (Aerts et al., 1996) but also from the fact that the soil available $\mathrm{N}$ concentration is relatively low because of limited precipitation and low temperature (Tian et al., 2010), finally resulting in lower plant $\mathrm{N}$ concentrations in this alpine grassland.

$\mathrm{N}$ addition did not show any significant impact on plant $\mathrm{C}$ concentrations, but it increased plant biomass and led to more $\mathrm{C}$ sequestration in plants. Our results showed that $\mathrm{N}$ addition significantly increased leaf $\mathrm{N}$ concentrations. Increases in plant $\mathrm{N}$ concentrations following $\mathrm{N}$ addition have been well documented in many previous studies (Xia and Wan, 2008; Peng et al., 2017; Hou et al., 2017; Wang et al., 2018). It seems that soil available $\mathrm{N}$ significantly increased after $\mathrm{N}$ addition, which provided an adequate soil nutrient supply for plant growth. This also implies that plant growth is affected by $\mathrm{N}$ availability but that plants can exhibit luxury uptake when $\mathrm{N}$ is not a limiting factor (Sistla et al., 2015), hence carrying higher $\mathrm{N}$ concentrations. On the other hand, $\mathrm{N}$ addition significantly reduced the $\mathrm{P}$ concentration for grass species but did not show any effect on the $\mathrm{P}$ concentrations of forb species. In contrast, many previous studies indicated an increase in plant $\mathrm{P}$ concentration in response to N addition (Lü et al., 2013; Hou et al., 2017; Wang et al., 2018). Simultaneously, many studies also found that $\mathrm{N}$ addition significantly increased soil P availability in grassland ecosystems (Lü et al., 2013; Han et al., 2014; Li et al., 2016). This difference can be explained as follows. First, $\mathrm{N}$ addition significantly increased plant aboveground biomass for grass species in our study, which would have partly diluted the P content in plants (Hou et al., 2017). Second, N addition had an ignorable impact on the soil available $\mathrm{P}$ content and soil alkaline phosphatase activity, which would have direct effects on reducing the plant $\mathrm{P}$ concentrations. Hence, $\mathrm{N}$ addition had positive, negative and neutral effects on plant $\mathrm{P}$ concentrations (You et al., 2018), which partly supports our findings that $\mathrm{N}$ addition decreased or had no effect on plant $\mathrm{P}$ concentrations depending upon species identity. For instance, $\mathrm{N}$ fertilization decreased $\mathrm{P}$ concentrations in leaves of dominant grasses by $40 \%$ in an annual grassland 
(Menge and Field, 2007), while it had neutral effects on plant P concentrations for forb species in semiarid grasslands (Hou et al., 2017).

Our results clearly demonstrated that the N:P ratio in leaves was enhanced after $\mathrm{N}$ addition. These findings are in accordance with previous studies (Lü et al., 2013; Zhan et al., 2018), where they found that increased $\mathrm{N}$ deposition can induce a shift from $\mathrm{N}$ to $\mathrm{P}$ limitation or N-P colimitation. Furthermore, plant N and P concentrations showed opposite responses to each other, indicating nutrient decoupling in plants under $\mathrm{N}$ deposition. These outcomes are not consistent with previous reports that observed that plant $\mathrm{N}$ and $\mathrm{P}$ are tightly coupled in grassland ecosystems (Agren et al., 2012; Lü et al., 2013). It is possible that altered soil nutrient availability by $\mathrm{N}$ addition could have reduced the leaf $\mathrm{C}: \mathrm{N}$ ratio, which would have promoted litter decomposition (Manzonl et al., 2010), because enhanced litter quality significantly promoted litter decomposition (Manzonl et al., 2010). Moreover, an increase in $\mathrm{N}$ inputs through fossil fuel combustion and cropland fertilization can greatly enhance the substrate nutrient availability for plants, which may also result in nutrient decoupling in plants, thus negatively influencing the plant community structures (Liu et al., 2015). For grass species, the responses of plant $\mathrm{N}$ and $\mathrm{P}$ concentrations and stoichiometric ratios following $\mathrm{N}$ addition could be controlled by soil $\mathrm{N}$ availability and soil available $\mathrm{N}: \mathrm{P}$, and the data suggest that the $\mathrm{N}: \mathrm{P}$ ratio in plants and soils was strongly linked. Our results supported the idea that increasing $\mathrm{N}$ deposition not only induces changes in $\mathrm{N}$ concentrations directly but also leads to an indirect alteration in the soil available N:P ratio (Penuelas et al., 2012).

\section{Effects of $N$ addition on the nutrient status of leaves and stoichiometric ratios at the functional group and community levels}

Our results indicated that leaf $\mathrm{C}$ remained relatively stable along the $\mathrm{N}$ addition levels at the functional group and community levels. However, $\mathrm{N}$ and $\mathrm{P}$ in leaves varied greatly among different plant functional groups. Nitrogen addition increased the $\mathrm{N}$ concentration and decreased the $\mathrm{P}$ concentration in leaves for the grass functional group; however, it showed a non-significant impact on $\mathrm{N}$ and $\mathrm{P}$ for the forb functional group. Nonetheless, $\mathrm{N}$ addition consistently increased the $\mathrm{N}$ concentration and decreased the $\mathrm{P}$ concentration at the community level. The responses of $\mathrm{P}$ concentration towards $\mathrm{N}$ addition were negative and neutral at functional group levels; thus, $\mathrm{N}$ addition did not enhance plant $\mathrm{P}$ uptake. These results are in line with the findings of (Hou et al., 2017; Wang et al., 2018), who described that $\mathrm{N}$ addition significantly increased the $\mathrm{P}$ concentration in grass species but had no impact on the $\mathrm{P}$ concentration of forb functional groups or community levels. This might have occurred because $\mathrm{N}$ addition did not affect soil phosphatase activity, leading to non-significant changes in soil $\mathrm{P}$ availability under long-term $\mathrm{N}$ addition. Furthermore, dominant grass species drove community-level $\mathrm{N}$ and $\mathrm{P}$ concentrations, which is also consistent with previous reports from typical steppe (Lü et al., 2018) and meadow steppe (Wang et al., 2018). The nutrient and stoichiometric responses of grass species to $\mathrm{N}$ addition are more sensitive than those of forb species, and the biomass of grass species was significantly enhanced, which could be a mechanism by which plants adapt to environmental changes, such as $\mathrm{N}$ deposition (Yu et al., 2010).

Nitrogen addition consistently decreased the C:N ratio and increased the N:P ratio in leaves at the functional group and community levels. Lower $\mathrm{C}: \mathrm{N}$ ratios generally show fast decomposition (Hou et al., 2017). In our study, N addition significantly enhanced leaf quality and contributed to decomposition in this alpine grassland. $\mathrm{N}: \mathrm{P}$ ratios have been used to determine relative nutrient limitation (Zhan et al., 2017) and regulate litter 
decomposition processes (Güsewell and Gessner, 2009). The enhancement of N:P ratios following $\mathrm{N}$ addition led to the decoupling of plant $\mathrm{N}$ and $\mathrm{P}$, which agreed with many studies from diverse ecosystems, such as grasslands (Wang et al., 2018), wetlands (Mao et al., 2012) and desert ecosystems (Huang et al., 2018), indicating that $\mathrm{N}$ addition may alleviate N limitation and intensify P limitation. However, Han et al. (2014) found that N addition significantly increased $\mathrm{P}$ concentrations and $\mathrm{C}: \mathrm{P}$ ratios at the species level, and this phenomenon was not observed at the community level. Furthermore, N addition significantly increased plant aboveground biomass, but only in one of the six species with the largest biomass was at the highest $\mathrm{N}$ addition, which implied that the growth of most species was not limited by $\mathrm{N}$ availability. If plant growth is limited by $\mathrm{N}, \mathrm{N}$ addition will further promote plant growth. Considering the current high $\mathrm{N}$ deposition in China, plant growth may be limited by soil $\mathrm{P}$ availability in grassland ecosystems because the soil available $\mathrm{P}$ content was relatively lower than that in other regions (Han et al., 2005; Zhang et al., 2005). In brief, our results suggested that the $\mathrm{N}$ and $\mathrm{P}$ of plants from the species to community levels revealed divergent responses to long-term $\mathrm{N}$ addition in this alpine grassland, but the specific mechanism still needs to be explored further.

\section{Soil available $N$ and available $N: P$ ratio as determining factors for plant nutrient concentrations and stoichiometric ratios}

It has been well established that soil available $\mathrm{N}$ is a strong predictor of plant nutrient concentrations and stoichiometric ratios (Lü et al., 2013; Zheng et al., 2018). In our study, we confirmed that $\mathrm{N}$ addition directly affected plant $\mathrm{N}$ and $\mathrm{P}$ concentrations and stoichiometric ratios at the species and community levels by enhancing soil available $\mathrm{N}$ concentrations rather than through soil available $\mathrm{P}$ in this alpine grassland, which is in agreement with the results reported from alpine steppe ecosystems (Peng et al., 2017). Compared with soil available $\mathrm{N}$ concentrations, the effects of soil available $\mathrm{P}$ on plant nutrient concentrations and stoichiometric ratios could be considered minimal because long-term $\mathrm{N}$ addition did not cause significant changes in soil $\mathrm{P}$ availability among treatments.

Our results suggested that altered soil AN:AP ratio significantly affected plant nutrient status. For instance, plant $\mathrm{N}$ concentrations showed a significant positive relationship with the soil AN:AP ratio, but plant $\mathrm{P}$ concentrations had a significantly negative relationship with the soil AN:AP ratio at the species and community levels. This indicated that the responses of plant nutrient concentrations and stoichiometric ratios to $\mathrm{N}$ addition could be controlled by the soil available $\mathrm{N}: \mathrm{P}$ ratio, and this $\mathrm{N}: \mathrm{P}$ ratio in plants and soil is strongly coupled (Lü et al., 2013; Li et al., 2020). In desert grassland ecosystems, Zheng et al. (2018) found a positive linear correlation between the plant available N:P ratio and the leaf N:P ratio. In addition, Zhan et al. (2017) discovered that the leaf $\mathrm{N}: \mathrm{P}$ ratio is positively correlated with the soil available $\mathrm{N}: \mathrm{P}$ ratio across $\mathrm{N}$ addition treatments. These findings highlight the importance of the soil available $\mathrm{N}: \mathrm{P}$ ratio in controlling plant nutrient status in alpine grassland ecosystems. This means that enhancing $\mathrm{N}$ deposition would change the plant community composition and plant internal nutrient cycling through direct alteration in soil $\mathrm{N}$ availability and by indirect changes in soil nutrient stoichiometry. 


\section{Conclusion}

The divergent responses of plant $\mathrm{N}$ and $\mathrm{P}$ concentrations in leaves to long-term $\mathrm{N}$ addition at the species and community levels implied that plant $\mathrm{N}$ and $\mathrm{P}$ cycling decoupled under $\mathrm{N}$ deposition. Grasses were more sensitive to $\mathrm{N}$ addition than forbs, resulting in significantly altered plant community composition. Moreover, soil available $\mathrm{N}$ and the soil available $\mathrm{N}: \mathrm{P}$ ratio, rather than soil available $\mathrm{P}$, were the key environmental parameters that controlled the $\mathrm{N}$ and $\mathrm{P}$ concentrations and stoichiometric ratios in plants. These findings are important for understanding plant nutrient allocation strategies and how plants adapt to environmental changes in alpine ecosystems. Altered plant community composition of forb species by $\mathrm{N}$ addition has minor influences on leaf nutrient status. Briefly, these findings have important implications for understanding the influence of $\mathrm{N}$ deposition on grassland nutrient cycling. In the future, biogeochemical models should consider the divergent responses of plant nutrient cycling to nutrient changes.

Acknowledgements. This research was supported by the National Natural Science Foundation of China (41673079, 41425007) and "Light of West China" Program of the Chinese Academy of Sciences (Han W. $\mathrm{X}$.). We are also highly grateful to the Bayinbuluk Grassland Ecosystem Research Station, Chinese Academy of Sciences, for their help in field work.

\section{REFERENCES}

[1] Aerts, R. (1996): Nutrient resorption from senescing leaves of perennials: Are there general patterns? - Journal of Ecology 84: 597-608.

[2] Ågren, G. I., Wetterstedt, J. A. M., Billberger, M. F. K. (2012): Nutrient limitation on terrestrial plant growth - modeling the interaction between nitrogen and phosphorus. - New Phytologist 194: 953-960.

[3] Bai, Y. F., Wu, J. G., Clark, C. O., Naeem, S., Pan, Q. M., Huang, J. H., Zhang, L. X., Han, X. G. (2010): Tradeoffs and thresholds in the effects of nitrogen addition on biodiversity and ecosystem functioning: evidence from inner Mongolia Grasslands. - Global Change Biology 16: 358-372.

[4] Burton, A. J., Jarvey, J. C., Jarvi, M. P., Zak, D. R., Pregitzer, K. S. (2012): Chronic N deposition alters root respiration-tissue $\mathrm{N}$ relationship in northern hardwood forests. Global Change Biology 18: 258-66.

[5] Elser, J. J., Bracken, M. E. S., Cleland, E. E., Gruner, D. S., Harpole, W. S., Hillebrand, H., Ngai, J. T., Seabloom, E. W., Shurin, J. B., Smith, J. E. (2007): Global analysis of nitrogen and phosphorus limitation of primary producers in freshwater, marine and terrestrial ecosystems. - Ecology Letters 10: 1135-1142.

[6] Feng, X., Wang, R. Z., Yu, Q., Cao, Y. Z., Zhang, Y. G., Yang, L. J., Dijkstra, F. A., Jiang, Y. (2019): Decoupling of plant and soil metal nutrients as affected by nitrogen addition in a meadow steppe. - Plant Soil 443: 337-351.

[7] Gu, B., Ju. X. T., Chang, J., Ge, Y., Vitousek, P. M. (2015): Integrated reactive nitrogen budgets and future trends in china. - Proceedings of the National Academy of Sciences 112(28): 8792-8797.

[8] Güsewell, S. (2004): N:P ratios in terrestrial plants: variation and functional significance. - New Phytologist 164: 243-266.

[9] Güsewell, S., Gessner, M. O. (2009): N:P ratios influence litter decomposition and colonization by fungi and bacteria in microcosms. - Functional Ecology 23: 211-219. 
[10] Han, W. X., Fang, J. Y., Guo, D. L., Zhang, Y. (2005): Leaf nitrogen and phosphorus stoichiometry across 753 terrestrial plant species in China. - New Phytologist 168: 377 385.

[11] Han, X., Sistla, S. A., Zhang, Y. H., Lu, X. T., Han, X. G. (2014): Hierarchical responses of plant stoichiometry to nitrogen deposition and mowing in a temperate steppe. - Plant Soil 382: 175-187.

[12] He, J. S., Fang, J. Y., Wang, Z. H., Guo, D. L., Flynn, D. F. B., Geng, Z. (2006): Stoichiometry and large-scale patterns of leaf carbon and nitrogen in the grassland biomes of China. - Oecologia 149: 115-22.

[13] He, J. S., Wang, L., Flynn, D. F. B., Wang, X. P., Ma, W. H., Fang, J. Y. (2008): Leaf nitrogen:phosphorus stoichiometry across Chinese grassland biomes. - Oecologia 155: 301-310.

[14] Hou, S. L., Yin, J. X., Yang, J. J., Wei, H. W., Yang, G. J., Hu, Y. Y., Han, X. G., Lü, X. T. (2017): Consistent responses of litter stoichiometry to $\mathrm{N}$ addition across different biological organization levels in a semi-arid grassland. - Plant Soil 421: 191-202.

[15] Huang, G., Su, Y. G., Mu, X. H., Li, Y. (2018): Foliar nutrient resorption responses of three life-form plants to water and nitrogen additions in a temperate desert. - Plant Soil 424: 479489.

[16] Huang, J., Liu, J. X., Zhang, W., Cai, X. A., Liu, L., Zheng, M. H., Mo, J. M. (2019): Effects of urbanization on plant phosphorus availability in broadleaf and needleleaf subtropical forests. - Science of the Total Environment 684: 50-57.

[17] Kozovits, A., Bustamante, M., Garofalo, C., Bucci, S., Franco, A. C., Goldstein, G., Meinzer, F. C. (2007): Nutrient resorption and patterns of litter production and decomposition in a Neotropical Savanna. - Functional Ecology 21: 1034-1043.

[18] Li, K. H., Gong, Y. M., Song, W., Lv, J. L., Chang, Y. H., Hu, Y. K., Tian, C. Y., Christie, P., Liu, X. J. (2012): No significant nitrous oxide emissions during spring thaw under grazing and nitrogen addition in an alpine grassland. - Global Change Biology 18: 25462554.

[19] Li, K. H., Liu, X. J., Song, L., Gong, Y. M., Lu, C. F., Yue, P., Tian, C. Y., Zhang, F. S. (2015): Response of alpine grassland to elevated nitrogen deposition and water supply in China. - Oecologia 177: 65-72.

[20] Li, L., Gao, X. P., Li, X. Y., Lin, L. S., Zeng, F. J., Gui, D. W., Lu, Y. (2016): Nitrogen (N) and phosphorus $(\mathrm{P})$ resorption of two dominant alpine perennial grass species in response to contrasting $\mathrm{N}$ and $\mathrm{P}$ availability. - Environmental and Experimental Botany 127: 37-44.

[21] Li, L., Li, X. Y., Liu, B., Lei, J. Q., Yue, Z. W., Li, C. D. (2020): Nitrogen and phosphorus addition differentially affect plant ecological stoichiometry in desert grassland. - Acta Oecologica 102: 1035-1041.

[22] Liu, W. X., Jiang, L., Hu, S. J., Li, L. H., Liu, L. L., Wan, S. Q. (2015): Decoupling of soil microbes and plants with increasing anthropogenic nitrogen inputs in a temperate steppe. - Soil Biology and Biochemistry 72: 116-122.

[23] Lü, X. T., Kong, D. L., Pan, Q. M., Simmons, M. E., Han, X. G. (2012): Nitrogen and water availability interact to affect leaf stoichiometry in a semi-arid grassland. - Oecologia 168: 301-310.

[24] Lü, X. T., Reed, S., Yu, Q., He, N. P., Wang, Z. W., Han, X. G. (2013): Convergent responses of nitrogen and phosphorus resorption to nitrogen inputs in a semiarid grassland. - Global Change Biology 19: 2775-2784.

[25] Lü, X. T., Hu, Y. Y., Zhang, H. Y., Wei, H. W., Hou, S. L., Yang, G. J., Liu, Z. Y., Wang, X. B. (2018): Intraspecific variation drives community-level stoichiometric responses to nitrogen and water enrichment in a temperate steppe. - Plant Soil 423: 307-315.

[26] Manzoni, S., Trofymow, J. A., Jackson, R. B., Porporato, A. (2010): Stoichiometric controls on carbon, nitrogen, and phosphorus dynamics in decomposing litter. - Ecological Monographs 80(1): 89-106. 
[27] Mao, R., Song, C. C., Zhang, X. H., Wang, X. W., Zhang, Z. H. (2012): Response of leaves, sheath and stem nutrient resorption to 7 years of $\mathrm{N}$ addition in freshwater wetland of Northeast China. - Plant Soil 364: 385-394.

[28] Menge, D. N. L., Field, C. B. (2007): Simulated global changes alter phosphorus demand in annual grassland. - Global Change Biology 13: 2582-2591.

[29] Peng, Y. F., Li, F., Zhou, G. Y., Fang, K., Zhang, D. Y., Li, C. B., Yang, G. B., Wang, G. Q., Wang, J., Yang, Y. H. (2017): Linkages of plant stoichiometry to ecosystem production and carbon fluxes with increasing nitrogen inputs in an alpine steppe. - Global Change Biology 23: 5249-5259.

[30] Peñuelas, J., Sardans, J., Rivas-Ubach, A., Janssens, I. A. (2012): The human-induced imbalance between C, N and P in Earth's life system. - Global Change Biology 18: 3-6.

[31] Sardans, J., Peñuelas, J. (2015): Potassium: a neglected nutrient in global change. - Global Ecology and Biogeography 24: 261-275.

[32] Sistla, S. A., Appling, A. P., Lewandowska, A. M., Taylor, B. N., Wolf, A. A. (2015): Stoichiometric flexibility in response to fertilization along gradients of environmental and organismal nutrient richness. - Oikos 124: 949-959.

[33] Sterner, R. W., Elser, J. J. (2002): Ecological stoichiometry: the biology of elements from moleculas to the biosphere. - Prinecton University Press.

[34] Tian, H., Chen, G., Zhang, C., Melillo, J. M., Hall, C. A. S. (2009): Pattern and variation of C:N:P ratios in China's soils: a synthesis of observational data. - Biogeochemistry 98: 139-151.

[35] Wang, H. Y., Wang, Z. W., Ding, R., Hou, S. L., Yang, G. J., Lü, X. T., Han, X. G. (2018): The impacts of nitrogen deposition on community N:P stoichiometry do not depend on phosphorus availability in a temperate meadow steppe. - Environmental Pollution 242: 8289.

[36] Xia, J. Y., Wan, S. Q. (2008): Global response patterns of terrestrial plant species to nitrogen addition. - New Phytologist 179: 428-439.

[37] You, C. M., Wu, F. Z., Yang, W. Q., Xu, Z. F., Tan, B., Yue, K., Ni, X. Y. (2018): Nutrientlimited conditions determine the responses of foliar nitrogen and phosphorus stoichiometry to nitrogen addition: A global meta-analysis. - Environmental Pollution 241: 740-749.

[38] Yu, Q., Chen, Q. S., Elser, J. J., He, N. P., Wu, H. H., Zhang, G. M., Wu, J. G., Bai, Y. F., Han, X. G. (2010): Linking stoichiometric homoeostasis with ecosystem structure, functioning and stability. - Ecology Letters 13: 1390-1399.

[39] Yue, P., Li, K. H., Gong, Y. M., Hu, Y. K., Mohammat, A. W., Christie, P. A., Liu, X. J. (2016): A five-year study of the impact of nitrogen addition on methane uptake in alpine grassland. - Scientific Reports 6: 32064-32071.

[40] Zhan, S. X., Wang, Y., Zhu, Z. C., Li, W. H., Bai, Y. F. (2017): Nitrogen enrichment alters plant $\mathrm{N}$ : $\mathrm{P}$ stoichiometry and intensifies phosphorus limitation in a steppe ecosystem. Environmental and Experimental Botany 134: 21-32.

[41] Zhang, C., Tian, H. Q., Liu, J. Y., Wang, S. Q., Liu, M. L., Pan, S. F., Shi, X. Z. (2005): Pools and distributions of soil phosphorus in China. - Global Biogeochemical Cycle 19: 1020-2028.

[42] Zhang, J. J., Yan, X. B., Su, F. L., Li, Z., Wang, Y., Wei, Y. A., Ji, Y. G., Yang, Y., Zhou, X. H., Guo, H., Hu, S. J. (2018): Long-term N and P additions alter the scaling of plant nitrogen to phosphorus in a Tibetan alpine meadow. - Science of the Total Environment 625: 440-448.

[43] Zheng, J., She, W. W., Zhang, Y. Q., Bai, Y. X., Qin, S. G., Wu, B. (2018): Nitrogen enrichment alters nutrient resorption and exacerbates phosphorus limitation in the desert shrub Artemisia ordosica. - Ecology and Evolution 8: 9998-10007.

[44] Zhou, X. L., Guo, Z., Zhang, P. F., Du, G. Z. (2018): Shift in community functional composition following nitrogen fertilization in an alpine meadow through intraspecific trait variation and community composition change. - Plant Soil 431: 289-302. 
[45] Zhou, T. C., Sun, J., Liu, M., Shi, P. L., Zhang, X. B., Sun, W., Yang, G., Tsunekawa, A. (2020): Coupling between plant nitrogen and phosphorus along water and heat gradients in alpine grassland. - Science of the Total Environment 701: 134660. 